IZA DP No. 6272

Men's Sexual Orientation and Job Satisfaction

Nick Drydakis

January 2012 


\title{
Men's Sexual Orientation and Job Satisfaction
}

\author{
Nick Drydakis \\ University of Patras, \\ Scientific Centre for the Study of Discrimination, Athens \\ and IZA
}
Discussion Paper No. 6272
January 2012

\author{
IZA \\ P.O. Box 7240 \\ 53072 Bonn \\ Germany \\ Phone: +49-228-3894-0 \\ Fax: +49-228-3894-180 \\ E-mail: iza@iza.org
}

Any opinions expressed here are those of the author(s) and not those of IZA. Research published in this series may include views on policy, but the institute itself takes no institutional policy positions.

The Institute for the Study of Labor (IZA) in Bonn is a local and virtual international research center and a place of communication between science, politics and business. IZA is an independent nonprofit organization supported by Deutsche Post Foundation. The center is associated with the University of Bonn and offers a stimulating research environment through its international network, workshops and conferences, data service, project support, research visits and doctoral program. IZA engages in (i) original and internationally competitive research in all fields of labor economics, (ii) development of policy concepts, and (iii) dissemination of research results and concepts to the interested public.

IZA Discussion Papers often represent preliminary work and are circulated to encourage discussion. Citation of such a paper should account for its provisional character. A revised version may be available directly from the author. 


\section{ABSTRACT}

\section{Men's Sexual Orientation and Job Satisfaction}

This study investigates the differences in three aspects of job satisfaction - total pay, promotion prospects, and respect received from one's supervisor - between male heterosexual and gay employees in Athens, Greece. Gay employees are found to be less satisfied according to all job satisfaction measures. Affect Theory proposes that the extent to which one values a given facet of work moderates how dissatisfied one becomes when one's expectations are not met. Furthermore, the data enable us to estimate that gay employees' job satisfaction is not associated more (as compared to heterosexuals' job satisfaction) with adverse mental health symptoms. This finding is crucial given the rising interest between job satisfaction and life satisfaction. Finally, wage gaps against gay employees are found after accounting for basic asymmetries. Interestingly, however, the wage gaps grow for very dissatisfied employees and shrink for very satisfied employees. As long as, the general patterns in Greece suggest that homosexual employees face labour market discrimination, gay employees will report being less satisfied at work. Actually, in this study, job satisfaction is associated with wage inequality. This research initiates efforts to compare job satisfaction based on sexual orientation.

JEL Classification: J28, C93, J7, J16, J31, J42, J64, J71

Keywords: job satisfaction, sexual orientation

Corresponding author:

Nick Drydakis

Department of Economics

University of Patras

University Campus

26504, Rio

Greece

E-mail: ndrydakis@econ.soc.uoc.gr 


\section{Introduction}

Recent years have seen an increase in social scientists' interest in the analysis of job satisfaction (Frey and Stutzer, 2002), and a sizeable amount of research has been devoted to developing conceptual definitions of the job satisfaction construct. Locke (1976) provides the seminal definition of job satisfaction: "a pleasurable or positive emotional state resulting from an appraisal of one's job or job experiences" (p. 1304). Building on this conceptualisation, Hulin and Judge (2003) noted that job satisfaction includes multidimensional psychological responses to one's job and that such responses have cognitive, affective, and behavioural components ${ }^{1}$. A few empirical studies demonstrate the impact of job satisfaction on many issues, and the validity of these satisfaction studies is important for a number of reasons (Saari and Judge, 2004). Green (2010) suggests that job satisfaction predicts future quitting. Drago and Wooden (1992) show that job satisfaction responses are negatively correlated with absenteeism. Judge et al (2001) in a comprehensive review of 301 studies, found that job satisfaction is predictive of performance; that is, a happy worker is a productive worker. Patterson et al

1 Most researchers understand job satisfaction as a global concept that comprises various facets. Warr (1999) classifies the job-related determinants of job satisfaction into ten job features: personal control, opportunity for skill use, job demands, variety, environmental clarity (including job security), income, physical security, supportive supervision, interpersonal contact, and a valued social position. Higher job satisfaction may be due to improvements in the objective aspects of the job, to reduced expectations or to downplaying dissatisfying aspects of the job while giving greater weight to pleasing aspects (Warr, 1999). 
(2004) show the same pattern. Furthermore, Mount et al (2006) show that job satisfaction can partially mediate the relations between personality variables and deviant work behaviours. Faragher et al (2005) in a meta-analysis of 485 studies, suggest that job satisfaction level is an important factor influencing workers' health. The existence of such relations suggests that the analysis of employees' subjective well-being and the understanding of what makes different groups of workers satisfied can provide a number of insights into the most important labour market behaviours: productivity, absenteeism, quitting, work behaviour, and health behaviour.

Previous economic research on job satisfaction has allowed for heterogeneous effects between sexes (Clark, 1997; Gazioglu and Tansel, 2006) and health conditions (Uppal, 2005; Pagán and Malo, 2009; Drydakis 2012a). The current study adds to the literature by examining the relation between job satisfaction and men's sexual orientation by utilizing data from the 2008 Athens Area Study (AAS). The satisfaction that gay employees derive from their jobs could be viewed as a reflection of how they respond to job characteristics, and many social scientists would consider the understanding of a minority group's well-being to be one of their principal concerns, and it is therefore surprising that only two similar studies have been carried out to capture some relevant patterns. Carpenter (2005a) using the 2003 Canadian Community Health Survey, restricted to a subsample of individuals living in three health regions of the Canadian provinces (Ontario, Newfoundland, and Saskatchewan), presents evidence on differences in job satisfaction by sexual orientation. The author estimates that gay men report statistically significant higher job satisfaction, although they have poorer economic outcomes than similarly situated heterosexual men. On the other hand, lesbians report statistically significant higher job satisfaction, although they have higher 
earnings than comparable heterosexual women. Thus, it is not certain that any pecuniary advantage experienced by employees in the labour market could directly reflect or translate into more job satisfaction. In addition, Carpenter (2008) using the 2000 Longitudinal Survey of Women's Health for Australian women age 22-27, finds evidence that lesbians are statistically significant less satisfied with their achievements pertaining to work compared to otherwise similar heterosexual women. Those young lesbians fare worse than similarly situated heterosexual women along almost every dimension related to economic well being. In actuality, in the literature, there is stronger evidence of pecuniary discrimination against gay men than against lesbians. In this study, we make no attempt to study lesbians' pecuniary and non-pecuniary outcomes. Badgett et al (2007), Carpenter (2008), as well as, Drydakis (2011) discuss many relevant issues.

As regards gay men, historical, sociological, and psychological research demonstrates the existence of sexual prejudice (negative attitudes based on sexual orientation) and the effects that such attitudes have on the everyday experiences of them (Herek, 2000). Gay employees who are subject to unequal treatment at work describe a variety of experiences that range from discomfort and signs of embarrassment on the part of managers and colleagues to exclusion and insults by colleagues (European Union Agency for Fundamental Rights report, 2009). Moreover, researchers recount instances of institutionalised procedures to restrict officially conferred work rewards, such as promotions, salary increases or increased job responsibilities (Badgett et al, 2007). In view of these facts, one could predict that gay employees are more likely to report lower job satisfaction: Hypothesis 1. The rationale for such low expectations is 
the disadvantaged position of gay workers in the labour market ${ }^{2}$. Perceived discrimination, harassment and discriminatory payments and promotions are suggested to decrease job satisfaction (Mirage, 1994; Sanchez and Brock, 1996). However, one could also claim that due to prejudices, gay employees may have low expectations about what they can obtain from work. In such cases, gay employees would be expected to have higher satisfaction in almost any type of job with respect to heterosexuals: Hypothesis 2. If we assume that homosexuality confers a poor position in the labour market and that gay employees who are in the labour market feel advantaged, we can suggest that there is a positive influence of homosexuality on job satisfaction. Indeed, Clark (1997), Souza-Poza and Souza-Poza (2003), Gazioglu and Tansel (2006) and Drydakis (2012a) estimate women to be more satisfied with their work than men,

\footnotetext{
${ }^{2}$ In the United States, Black et al (2003) employed the General Social Survey data from 1989-1996 and found earnings to be between $14 \%$ and $16 \%$ lower for behaviourally (defined in various ways depending on the presence of a same-sex partner) gay men than for heterosexuals. Studies of self-reported gay men in the Netherlands between 1998 and 2002 found that such men earned approximately 4\% less than heterosexuals (Plug and Berkhout, 2004). In the United Kingdom, Arabsheibani et al (2005), using data from the Labour Force Survey between 2001 and 2005, found that gay men, identified as individuals living with same sex partners, earned about 5\% less than heterosexuals. In Sweden, Ahmed and Hammarstedt (2010), using data from the LOUISE database at Statistics Sweden, found that gay men who were living in civil unions in the year 2003 were at a 10-15\% earnings disadvantage compared with male heterosexuals.
} 
perhaps because women have gained a better position in the market relative to their expectations; this is the so-called gender/job-satisfaction paradox (i.e., women receive lower wages than men do, but they are more satisfied at work than men are). Carpenter's gay estimations (2005a) may be linked to this hypothesis.

Who is the most satisfied in their work, and why do differences in satisfaction levels exist? The answers to these questions should be of interest to workers, employers, and social planners alike. The current study concludes that gay employees are less satisfied than their heterosexual counterparts according to all job satisfaction measures, even when a large number of productivity features and job characteristics are controlled for. Affect Theory (Locke, 1976) proposes that the extent to which one values a given facet of work moderates how dissatisfied one becomes when one's expectations are not met. Moreover, in the literature there is growing interest in whether employees' life satisfaction affects job satisfaction. The current sample enables us to investigate few patterns. The estimations suggest that gay employees' job satisfaction is not associated more (as compared to heterosexuals' job satisfaction) with adverse mental health symptoms. We suggest that gay men may learn to adapt to their mental health situation (Folkman and Moskowitz, 2003). Finally, it is suggested that job satisfaction may be a reflection of the returns to labour market activity because wage gaps against gay employees are found after accounting for productivity asymmetries. Interestingly, however, the wage gaps grow for very dissatisfied employees and shrink for very satisfied employees. As Hamermesh (2001) and Ferrer-i-Carbonell (2005) argue, as long as wages are a proxy for efficiency, indispensability, achievement and future potential, employees will rate their job satisfaction based on their wage. The fruitful outcomes of this study highlight that the knowledge of the job satisfaction level of a 
minority population is useful for helping social scientists understand a wide array of important questions about the general condition of the labour market.

The rest of the paper is divided into six sections. The next section briefly presents an overview of gay issues in the Greek labour market. Section 3 discusses the AAS data set. Section 4 discusses the descriptive statistics. Section 5 evaluates the estimation framework, presents the empirical estimations and offers a discussion. Section 6 concludes.

\section{Gay issues in Greece}

The hostile social and public policy climate in Greece is an important factor in understanding the lack of visibility of gays and lesbians and their issues in Greek society. In particular, the lack of legal recognition of family structures, the persistence

of threats and verbal violence, the perpetuation of false stereotypes, and the lack of political will shown by the authorities in the fight against discrimination demonstrate such attitudes (Drydakis, 2009). Greece is one of the most puritanical societies in the European Union in terms of general attitudes toward homosexuality. Eurobarometer (2007) reveals that a large majority of Greeks (85\%) feel that homosexuality is a taboo, compared to $48 \%$ of European Union respondents. A similarly large majority (84\%) share the opinion that it is difficult for gays to state their sexual orientation at work, compared to $68 \%$ of European Union respondents. Furthermore, sexual orientation appears to be the most common grounds for discrimination in the country, at $68 \%$.

Although academic studies can substantially contribute to our perception of factors affecting the employment opportunities of minority groups, data limitations in Greece remain a major obstacle to research on the gay population. Only two studies 
focus on the labour market success of gay men in Greece. Drydakis (2009) suggests that gay job seekers face lower occupational access and are offered lower entry wages, while Drydakis (2012b) finds that gay men face a higher unemployment rate $(8.1 \%)$ and receive lower monthly wages $(4.2 \%)$ than their heterosexual counterparts. Sexual orientation harassment and bullying in the workplace environment are also issues for openly gay employees (Drydakis, 2009).

The above features indicate that the current social situation of gay people represents a problem for Greece. In particular, these issues are especially striking when considered in the context of legislation aimed at securing improvements in the labour market position of sexual orientation minorities in Greece (Law 2005/3304). At the same time, the European Union has called for the member states' attention to the quality aspects of work and has emphasised the importance of improving job quality to promote social inclusion and employment (European Commission, 2002). European firms and employers should pay close attention to the subjective well-being of their employees and to how employees perceive their current jobs.

\section{Definition of variables}

The data were gathered from March 2008 to December 2008 in Athens, the capital of Greece, as part of the Athens Area Study (AAS) conducted by the University of Piraeus, University of Central Greece and Panteion University of Social and Political Sciences. The 2008 AAS is one component of the Multi-City Study of the Scientific Centre for the Study of Discrimination (SCSD). The current AAS consists of telephonebased surveys. Individuals in each household were randomly selected to provide 
information on a variety of demographic characteristics ${ }^{3}$, and the analysis was restricted to employed respondents aged 18 to 65 years (the upper limit corresponding to the official retirement age in Greece). The SCSD guards participants' anonymity in all research output. To investigate sexual orientation, workers were asked: "The next question is about sexual orientation: Do you consider yourself to be: (1) Heterosexual? (2) Homosexual?" Carpenter (2005b) argues that direct self-reports of sexual orientation offer a measure of sexuality that, in the context of labour market analyses, is preferable to behavioural measures (defined in a number of ways depending on the presence of a same-sex partner) used by most previous research. For convenience, all variables' definitions are summarised in Table 1.

Three measures of job satisfaction are available in the AAS dataset. The measures are total pay (including any overtime or bonuses), promotion prospects, and respect received from supervisors. There are many methods of measuring job satisfaction, the most common of which is the Likert scale (1932). The AAS follows the format of a typical five-level Likert item. The job facet satisfaction question reads, "I'm going to read you four aspects of jobs, and for each one, I'd like you to tell me which number best describes how satisfied or dissatisfied you are with that particular aspect of your own present job." Employees are asked to rate each job aspect on a scale from 1, "very dissatisfied," to 5, "very satisfied".

The AAS constructed an hourly wage measure by dividing the last month's wages, called HW, by self-reported working hours per month. Surveyors asked, "What

\footnotetext{
${ }^{3}$ The Athens Area Sample is random. We do not know the rate at which each household was sampled; it was a random process. Thus, we do not know the probability that a unit is included in the sample to construct its base weight.
} 
is your best estimate of your wage last month before taxes and other deductions?" The wage variable is the mean of the hourly wages (ln). The variable AGE measured the respondent's age in years. To allow for a non-linear relationship between job satisfaction and age, the square of age (AGESQ) was included in the regression. The variable MARR was set to one if the respondent was married and zero otherwise. The variable CHIL measured how many children the respondent has. The variable IMM was set to one if the respondent was an immigrant (non-Greek) and zero otherwise. The variable DIS was set to one if the individual's activities were limited by poor health and zero otherwise (see, Baldwin and Johnson, 2000). Similarly, the variable MHS measures adverse mental health symptoms experienced in the last week ${ }^{4}$. The scale defined by the Center for Epidemiology Studies (CES-D, 20 items), measures the existence of adverse mental health symptoms (life dissatisfaction), and studies have confirmed the validity and reliability of the score as a screening instrument for the evaluation of subjective well-being (Shenkman and Shmotkin; 2011).

The variable SCHOL was set to one if the respondent had completed the minimum mandatory education and zero otherwise. The variable GRAD was set to one if the respondent had graduated from high school and zero otherwise. The variable

4 This measure was designed to assess self-reported symptoms associated with depression (Radloff, 1977). The measure consists of 20 items describing major components of depressive symptomatology. Each individual was asked to rate for each item how often he had felt or behaved this way in the past week. Ratings ranged from 1 (rarely or none of the time, $<1$ day) to 4 (most or all of the time, 5-7 days). The ratings of four items were reversed. The participant's score was the items' mean rating, with a higher score indicating more depressive symptoms. 
UNIV was set to one if the respondent had a university or technical school diploma and zero otherwise. The variable PC was set to one if the respondent had computer skills and zero otherwise. The variable ENGL was set to one if the respondent had knowledge of English and zero otherwise. The variable EXPER measures the respondent's years of actual working experience. For reasons discussed above, we also included the square of actual experience (EXPERSQ).

The variable WHITE was set to one if the individual's occupation was considered white collar, and zero otherwise. Similarly, the variable BLUE was set to one if the individual's occupation was considered blue collar and zero otherwise. In addition the variable SERV was set to one if the individual's occupation was considered a service occupation, and zero otherwise. For greater occupational control, an additional variable was considered. The variable PUBL was set to one if the worker was employed in the public sector and zero if the employee was employed in the private sector (PRIV). In addition, the variable FULL was set to one if the individual was a full-time worker (in Greece, this means eight hours per day) and zero if the worker was a part-time worker (PART).

\section{Descriptive Statistics}

In Table 2, the AAS sample consists of 6,305 heterosexual, and 277 gay employees, representing a proportion of gay individuals on the order of $4.3 \%{ }^{5}$. Columns

\footnotetext{
${ }^{5}$ Some researchers have argued that gay men's decisions to live in a particular area depend on the area's prevailing social and political views towards the gay population (Murray, 1996; Arabsheibani et al, 2004). Similarly, in non-Athenian (i.e. nonmetropolitan) areas we expect lower percentage of gay population. Moreover, we expect
} 
1 and 2, shows descriptive statistics for heterosexual and gay employees, respectively ${ }^{6}$. At first glance, we see that gay employees have lower levels of job satisfaction than heterosexual employees in all specifications. The difference between the two groups is larger for satisfaction with respect received from supervisor, followed by satisfaction with promotion prospects, and finally satisfaction with total pay. These differences are statistically significant at the $1 \%$ level. We observe also that gay men have statistically significant lower hourly wages than heterosexuals. As expected, gays are statistically significant less likely to be married than heterosexuals. In addition, gays have statistically significant fewer children than heterosexuals. Moreover, gays are statistically insignificant more likely to have negative mental health symptoms than heterosexuals. On average, gay and heterosexual workers devote the same number of years to education, but gay men have statistically insignificant fewer years of working experience than heterosexuals. Furthermore, gay men are statistically significant less likely to be employed in white-collar jobs than heterosexuals. They are also statistically significant less likely to work in service occupations than heterosexuals, and they are

gay individuals to be less inclined to disclose their homosexuality in non-Athenian areas. However, according to Women and Health Initiative (2007) 8\% of Greeks (both sexes) self-reported not to be heterosexuals.

${ }^{6}$ In $6 \%$ of all cases, the respondents did not answer the relevant question regarding sexual orientation. The descriptive statistics between those who responded to the question and those who did not respond to the question are identical. In the estimation portion of the study, whether we include these observations (with a missing sexualorientation dummy) makes no difference to the coefficients. 
statistically insignificant less likely to be employed in the public sector than heterosexual men.

Table 3, shows the reported levels of job satisfaction in the AAS survey. For heterosexual employees the most frequent response for all measures of job satisfaction is "satisfied" category. On the other hand, for gay employees the most frequent response in all specifications is "neither dissatisfied nor satisfied". For gay employees "very dissatisfied" and "dissatisfied" categories are substantial, especially for satisfaction with promotion prospects and respect received from supervisor. For both groups "very satisfied" is unsubstantial, except for satisfaction received from supervisor for heterosexual employees. In all cases, the assigned job satisfaction difference between the two employee groups is statistically significant at the $1 \%$ level. On average, econometric analysis that takes all these variables into consideration is necessary to determine whether there is a significant job satisfaction difference between gay and heterosexual employees.

\section{Estimations and discussion}

In the current research, to analyse the three measures of job satisfaction, we use an ordered probit model, as in Clark (1997), Gazioglu and Tansel (2006) and Drydakis (2012a). This type of model contains generally similar sets of personal characteristics and varying sets of job-related characteristics as independent variables. Equation (1) presents an estimable specification of this basic model:

$S=\beta_{1} \mathrm{X}_{i}+\gamma_{1} G_{i}+\varepsilon_{1 i}$

where $S$ is a variable indicating the level of job satisfaction; $X_{i}$ is a vector of the characteristics that describe the employees; $G_{i}$ is a dummy variable that equals one if 
the individual is gay and zero otherwise; $\beta_{1}$, and $\gamma_{1}$ are the parameters to be estimated by the ordered probit model; and $\varepsilon_{1 \mathrm{i}}$ is the error term. The key variable of interest is the dummy variable indicating that the worker is gay. A statistically significant negative coefficient would imply lower job satisfaction for gay employees.

Table 4 presents the estimates of job satisfaction. The regression results confirm the initial descriptive statistics; namely, gay employees are statistically significant less satisfied at work than heterosexual employees. The estimation of satisfaction with total pay for gay men is lower by -0.214 than that for heterosexuals, generating a negative marginal effect on the order of 0.041 . Moreover, the estimation of satisfaction with promotion prospects for gay men is lower by -0.286 than that for heterosexuals, generating a negative marginal effect on the order of 0.047 . In addition, the estimation of satisfaction with respect received from one's supervisor for gay men is lower by 0.501 than that for heterosexuals, generating a negative marginal effect on the order of 0.064. As it is observed, the largest difference is found for satisfaction with the respect received from one's supervisor, followed by satisfaction with promotion prospects and satisfaction with total pay. Ordered probit estimations and marginal effects showed a strong negative effect of gay orientation on job satisfaction at the $1 \%$ level.

The European Union Agency for Fundamental Rights report (2009) and Drydakis $(2009 ; 2011 ; 2012 b)$ confirm that workplace discrimination and harassment are issues for sexual orientation minorities in Greece. The current findings highlight gay employees' intolerance of this workplace feature. Many studies confirm that workplace conditions are crucial in determining employees' job satisfaction (Byrgen, 2004). Indeed, based on Locke's Affect Theory $(1976,1984)$, how much one values a given facet of work moderates how dissatisfied one becomes when one's expectations are not 
met. Locke $(1976,1984)$ believed that satisfaction is determined by two factors: the have-want discrepancy and the importance of satisfaction. According to Locke's valuepercept model, job satisfaction can be modelled by the following formula:

Satisfaction $=($ Want - Have $) \times$ Importance of Satisfaction

According to McFarlin et al (1995), this is a result of the employee's comparing what he actually has in a job against what he ideally wants to have. It seems, then, that gay employees have higher expectations about what they will obtain from their work. These outcomes should be of interest to workers and employers alike. The importance of satisfaction refers now to the importance of each facet of the job within the worker's personal hierarchy of values (McFarlin et al, 1995). When a job facet's importance is high, one may experience the full range of affective reactions, from extreme satisfaction to extreme dissatisfaction. For gay employees, it seems that, dissatisfaction will be at its highest level when what is received does not match what is wanted and valued.

In the AAS, a straightforward relationship seems to hold; as long as the general patterns in Greece suggest that gay employees face discriminatory treatment in the labour market, are victims of harassment, and enjoy lower societal approval than heterosexuals, gay employees will report being significantly less satisfied at work; thus, we accept Hypothesis 1. Gay employees seem to have higher expectations of what they will obtain from their jobs, and one could suggest that once sexual orientation prejudices and biases in the labour market disappear, heterosexuals' and gays' reported satisfaction should be identical. However, this is an open question that needs longitudinal data to be examined. 
A number of results that are commonly obtained with international data are found to hold in the current study. In equations for all three measures of job satisfaction, age and age-squared are statistically significant and carry negative and positive signs, respectively, indicating a U-shaped relationship between age and job satisfaction (see, Clark, 1996; Gazioglu and Tansel, 2006). The same pattern holds for actual working experience, and actual working experience-squared. In all job satisfaction specifications, married employees appear to be significantly more satisfied at work than unmarried employees are (see, Clark, 1996). Moreover, immigrant employees appear to be significantly less satisfied than native employees in the three specifications (see, Gazioglu and Tansel, 2006). In all specifications, higher wages are positively correlated with higher job satisfaction levels (see, Clark, 1996). Further, employees with a university or technical school diploma are significantly less satisfied with their pay but significantly more satisfied with the respect they receive from their supervisor and with their promotion prospects (see, Clark, 1996). White-collar employees were found to be significantly more satisfied with the promotion prospects and respect received from their supervisor compared to employees in services. Moreover, public employees are always more satisfied in all job satisfaction categories compared to private employees (see, Clark et al, 1996; Gazioglu and Tansel, 2006).

Furthermore, employees with disabilities are always less satisfied at work (see, Uppal 2005; Gazioglu and Tansel, 2006). In addition, in equations for all three measures of job satisfaction, employees with more adverse mental health symptoms (life dissatisfaction) are always less satisfied at work than those who have fewer of these 
conditions $^{7}$. Indeed, various studies evaluate a positive correlation between life dissatisfaction and job dissatisfaction (Bowling et al, 2010). In this stage, it might be of further interest to estimate whether adverse mental health symptoms are associated with gay employees' job satisfaction more or less strongly. A term that interacts sexual orientation with adverse mental health symptoms is added to the basic equation (adverse mental health symptoms $x$ sexual orientation). The outcome suggests that neither heterosexuals' nor gays' job satisfaction is affected more by these symptoms. Depression, loneliness and other negative mental health characteristics are found to have the same negative associations with employees' job satisfaction regardless of sexual orientation ${ }^{8}$. One could expect gay Greeks to report higher life dissatisfaction

7 An endogeneity test evaluated by Rivers and Vuong (1988), and extended by Kawakatsu and Largey (2005) was employed to test whether the adverse mental health symptoms (CES-D 20 items) variable was endogenous in this step. Job dissatisfaction may lead to adverse mental health symptoms. For identification purposes not to solely rely on distributional assumptions, we choose "if individual has a partner" as the extra instrumental variable. All attempts brought no indications of endogeneity, rendering the framework appropriate. Importantly, one needs to take care in interpreting this result, and be cautious in making claims of causality.

${ }^{8}$ For convenience, the same pattern can be reached by regressing each sexual orientation group separately. For instance, we report here the adverse mental health symptoms coefficient for the satisfaction with total pay. For heterosexual men, the coefficient is estimated to be -0.011 , s.e. $0.004^{* * *}$, whereas for gay men, the coefficient equals -0.011 , s.e. $0.005^{* * *}$. The magnitude and the significance of the coefficients do 
than heterosexuals because gay people are subject to hostile societal feedback, prejudice, bias and discrimination. In the view of our estimations, however, we can suggest that it might be the case that simultaneous activation of the positive and negative affect systems generates an adaptive reaction among Greek gay employees. Many studies demonstrate that co-activation cultivates the exploration of novel environments and the pursuit of welcoming events and positive psychological adjustments while maintaining vigilance for hostile scenarios. Folkman and Moskowitz (2003) discuss patterns of the co-activation of emotions for homosexual individuals (see also, Larsen et al, 2001; Larsen et al, 2003; Shenkman and Shmotkin, 2011) ${ }^{9}$.

Finally, various studies suggest that job satisfaction measures could be useful not only to predict productivity, absenteeism, quitting, work behaviour, and health behaviour but also to unravel discriminatory treatments against minorities. Ferrer-iCarbonell (2005) argues that as long as wages are used as a proxy for efficiency, indispensability, achievement and future potential, employees will rate their job satisfaction based on their wage. Hamermesh (2001) also suggests that job satisfaction may be an important variable when analysing the inequality in the overall returns to work. Working in a collaborative spirit, one could suggest that the wage gap between comparable heterosexual and gay employees might partially drive the lower job satisfaction of the gay individuals in this sample. Actually, wage rate is the only not vary across sexual orientations (each result is the outcome of a separate regression). Complete estimations are available upon request.

${ }^{9}$ Importantly, note that, the AAS sample deals with adult employees who were prone to disclose their homosexuality, at least in this study. We expect that the adverse mental health symptoms could vary greatly if we had considered adolescents and/or students. 
relevant information we have in the AAS sample regarding work rewards. In the current stage, the above consideration can be examined and validated by estimating the sexual orientation wage difference for each satisfaction scale component across the three job satisfaction facets. The results from estimating Equation (1) for hourly wages ${ }^{10}$ confirm that wage difference between gay and heterosexual employees is lowest for the very satisfied category (from $0.7 \%$ to $1.6 \%$ ) and highest for the very dissatisfied category (from $5.6 \%$ to $6.8 \%$ ) across the three job satisfaction facets ${ }^{11}$. The wage difference between gay and heterosexual employees occasionally becomes statistically insignificant for those who reported being satisfied or very satisfied across the job satisfaction measures. It seems that job satisfaction is highly associated with wage inequality. From the economic perspective, job satisfaction is a unitary concept that can be explained in monetary terms. Since people are assumed to like rewards but dislike discrimination, a lower salary for an identical level of effort will determine a lower level of satisfaction. All of these patterns demonstrate the nature of multifaceted relationships and the need to explore them carefully.

Several factors demonstrate the importance of this study and its contribution to better understand gay employees' satisfaction compared to their heterosexual counterparts. Despite its strengths, most studies have weaknesses that limit the generalisability of the findings, and this study is no exception. The current findings are

${ }^{10}$ The empirical work is based on the standard human capital wage equation developed by Mincer (1974).

11 The evidence of the wage effects of sexual orientation has garnered a variety of economic explanations for its source (i.e. discrimination, gender roles, unobserved actual skills and work efforts). Drydakis (2012b) offers reviews and new findings. 
strictly applicable only to the time, place, employee demographic, and social and labour characteristics from which the sample was drawn. Moreover, an inevitable limitation of studies involving the disclosure of homosexuality is the response bias, which could influence the outcomes in both directions. Furthermore, we should note that employees' job satisfaction in the current study was associated with an adverse mental health symptom scale from the Center for Epidemiology Studies. We do not have valuable information based on other major scales. In addition, the current data are crosssectional, enabling us to draw conclusions only on the associations but not the causes.

Importantly, job satisfaction is a salient and perhaps inveterate attitude that permeates the cognitive, affective, and behavioural aspects of people's work and nonwork lives. These features demonstrate the importance of job satisfaction as a construct worthy of attention in the organisational sciences as well as in subjective well-being research in general. The reciprocal nature of job attitudes and subjective well-being means that a sound understanding of one domain is incomplete without due consideration to the other.

\section{Conclusion}

This study pursued the issue of differences in job satisfaction by examining the extent to which three aspects of job satisfaction - satisfaction with total pay, satisfaction with promotion prospects, and satisfaction with respect received from one's supervisor vary between gay and heterosexual employees. Utilising the AAS dataset (2008) the current study estimated several patterns. Gay employees were found to be less satisfied with all job satisfaction measures than their heterosexual counterparts, even when a large number of demographic, productivity and job features are controlled for. Based on 
Affect Theory we suggest that gay employees may have higher expectations about what they will obtain from their work. Of further importance was the finding that adverse mental health symptoms (life-dissatisfaction) decrease both heterosexual and gay employees' job satisfaction. However, these effects on job satisfaction did not vary between heterosexual and gay employees. It might be the case that simultaneous activation of the positive and negative affect systems generates an adaptive reaction among gay employees. Finally, job satisfaction may reflect the returns to labour market activity because wage gaps against gay employees are found after accounting for basic asymmetries. Interestingly, the wage gaps grow for very dissatisfied employees and shrink for very satisfied employees. The satisfaction that gay employees derive from their jobs can thus be viewed as reflecting how they react to their job's characteristics. If a variable such as job satisfaction contains useful information to predict behaviour (productivity, absenteeism, quitting, work behaviour, and health behaviour) and reflects the returns to labour market activity (wage inequality), it seems appropriate for social scientists to focus on this variable.

\section{References}

Ahmed, A. and Hammarstedt, M. (2010). Sexual Orientation and Earnings: a Register Data-Based Approach to Identify Homosexuals. Journal of Population Economics, 23, 836-49.

Arabsheibani, G. R. Marin, A. and Wadsworth, J. (2005). Gay Pay in the UK, Economica, 72:333-347. 
Badgett, L. M. V. Lau, H. Sears, B and Ho, D. (2007). Bias in the Workplace: Consistent Evidence of Sexual Orientation and Gender Identity Discrimination. The Williams Institute, UCLA School of Law.

Baldwin, L. M. and Johnson, W. G. (2000). Labour Market Discrimination Against Men with Disabilities in the Year of the ADA. Southern Economic Journal, 66:548566.

Black, D. A. Hoda, R. M. Seth, S. and Lower, T. (2003). The Earnings Effects of Sexual Orientation. Industrial and Labour Relations Review, 56, 449-69.

Bowling, N. A. Eschleman, K. J and Wang, Q. (2010). A Meta-Analytic Examination of the Relationship Between Job Satisfaction and Subjective Well-Being. Journal of Occupational and Organizational Psychology, 84:915-934.

Bygren, M. (2004). Pay Reference Standards and Pay Satisfaction: What do Workers Evaluate their Pay Against? Social Science Research, 33:206-24.

Carpenter, C. S. (2005a). Sexual Orientation and Economic Well-Being in Canada. Mimeo, The Paul Merage School of Business, University of California, Irvine.

Carpenter, C. S. (2005b). Self-Reported Sexual Orientation and Earnings: Evidence from California. Industrial and Labour Relations Review, 58:258-273. 
Carpenter, C. S. (2008). Sexual Orientation, Income, and Non-Pecuniary Economics Outcomes: New Evidence from Young Lesbians in Australia. Review of Economics of the Household, 4:391-408.

Clark, A. (1996). Job Satisfaction in Britain. British Journal of Industrial Relations, $34: 189-217$.

Clark, A. (1997). Job Satisfaction and Gender: Why are Women so Happy in Work? Labour Economics, 4:341-372.

Drago, R. and Wooden, M. (1992). The Determinants of Labor Absence: Economic Factors and Workgroup Norms across Countries. Industrial and Labor Market Review, 45: 764-778.

Drydakis, N. (2009). Sexual Orientation Discrimination in the Labour Market. Labour Economics, 16:364-372.

Drydakis N. (2011). Women's Sexual Orientation and Labor Market Outcomes in Greece. Feminist Economics, 11: 89-117.

Drydakis, N. (2012a). Health Impaired Employees' Job Satisfaction New Evidence from Athens, Greece. Applied Economics Letters, 19: 789-793. 
Drydakis, N. (2012b). Sexual Orientation and Labour Relations New Evidence from Athens, Greece. Applied Economics, 44:2653-2665.

Eurobarometer. (2007). Discrimination in the European Union, Wave 65.4. Brussels:European Commission.

European Commission. (2002). Employment in Europe, Chapter 5. Luxembourg: European Communities.

European Union Agency for Fundamental Rights. (2009). Homophobia and Discrimination on Grounds of Sexual Orientation and Gender Identity in the European Union Member States: Part II-The Social Situation. European Union: Vienna.

Faragher, E. B. Cass, M. Cooper, C. L. (2005). The Relationship Between Job Satisfaction and Health: a Meta-Analysis. Occupational and Environmental Medicine, 62:105-112.

Ferrer-i-Carbonell, A. (2005). Income and Well-Being: An Empirical Analysis of the Comparison Income Effect. Journal of Public Economics, 89:997-1019.

Folkman, S. and Moskowitz, J. T. (2003). Positive Psychology from a Coping Perspective. Psychological Inquiry: 14:121-125. 
Frey, B. and Stutzer, A. (2002). Happiness and Economics. New Jersey: Princeton University Press.

Gazioglu, S. and Tansel, A. (2006). Job satisfaction in Britain: Individual and Job Related Factors. Applied Economics, 38:1163 -1171.

Green, F. (2010). Well-Being, Job Satisfaction and Labour Mobility. Labour Economics, 17:897-903.

Hamermesh, D. S. (2001). The Changing Distribution of Job Satisfaction. Journal of Human Resources, 36: 1- 30.

Herek, G. M. (2000). The Psychology of Sexual Prejudice. Current Directions in Psychological Science, 9:19-22.

Hulin, C. L. and Judge, T. A. (2003). Job Attitudes, in Borman, W. C. Ilgen, D. R. and Klimoski, R. J. (Eds.), Handbook of Industrial and Organizational Psychology (p. 255-276). Hoboken, NJ: Wiley.

Judge, T. A. Thoresen, C. J. Bono, J. E. and Patton, G. K. (2001). The Job Satisfaction Job Performance Relationship: A Qualitative and Quantitative Review. Psychological Bulletin, 127: 376-407. 
Kawakatsu, H. and Largey, G. A. (2005). EM Algorithms for Ordered Probit Models with Endogenous Regressors. The Econometric Journal, 12:164-186.

Larsen, J. T. McGraw, A. P. and Cacioppo, J. T. (2001). Can People Feel Happy and Sad at the Same Time? Journal of Personality and Social Psychology, 81:684696.

Larsen, J. T. Hemenover, S. H. Norris, C. J. and Cacioppo, J. T. (2003). Turning Adversity to Advantage: On the Virtues of the Coactivation of Positive and Negative Emotions, in Aspinwall, L. G. and Staudinger, U. M. (Eds.), A Psychology of Human Strengths: Fundamental Questions and Future Directions for a Positive Psychology (p. 211-225). Washington, DC: American Psychological Association.

Likert, R. (1932). A Technique for the Measurement of Attitudes. Archives of Psychology, 140:1-55.

Locke, E. A. (1976). The Nature and Causes of Job Satisfaction, in Dunnette M. D. (Ed.). Handbook of Industrial and Organisational Psychology. Rand McNally, Chicago, USA.

Locke, E. A. (1984). Job Satisfaction, in Gruneberg, M. and Wall. T, (Eds.), Social Psychology and Organizational Behaviour (p. 92-117). London, England: John Willey and Sons. 
McFarlin, D. B. Coster, E. A. Rice, R. W. and Cooper, A. T. (1995). Facet Importance and Job Satisfaction: Another Look at the Range-of-Affect Hypothesis. Basic and Applied Social Psychology, 16:489-502.

Mincer, J. (1974): Schooling, Experience, and Earnings. New York: National Bureau of Economic Research.

Mirage, L. (1994). Development of an Instrument Measuring Valence of Ethnicity and Perception of Discrimination. Journal of Multicultural Counseling and Development, 22:49-59.

Mount, M. Ilies, R. and Johnson, E. (2006). Relationship of Personality Traits and Counterproductive Work Behaviors: The Mediating Effects of Job Satisfaction. Personnel Psychology, 59:591-622.

Murray, S. O. (1996). American Gay. University of Chicago Press, Chicago.

Pagán, R. and Malo M. Á. (2009). Job Satisfaction and Disability: Lower Expectations about Jobs or a Matter of Health? Spanish Economic Review, 11:51-74.

Patterson, M. Warr, P. and West, M. (2004). Organizational Climate and Company Productivity: The Role of Employee Affect and Employee Level. Journal of Occupational and Organizational Psychology, 77:193-216. 
Radloff, L. S. (1977). The CES-D Scale: A Self-Report Depression Scale for Research in the General Population. Journal of Applied Psychological Measures, 1:385401.

Rivers, D. and Vuong, Q. (1988). Limited Information Estimations and Exogeneity Tests for Simultaneous Probit Models. Journal of Econometrics, 39: 347-366.

Plug, E. and Berkhout, P. (2004). Effects of Sexual Preferences on Earnings in the Netherlands. Journal of Population Economics, 17, 117-131.

Saari, L. M. and Judge, T. A. (2004). Employee Attitudes and Job Satisfaction. Human Resource Management, 43:395-407.

Sanchez, J. I. and Brock, P. (1996). Outcomes of Perceived Discrimination among Hispanic Employees: Is Diversity Management a Luxury or a Necessity? Academy of Management Journal, 39:704-719.

Shenkman, G. and Shmotkin D. (2011) Mental Health Among Israeli Homosexual Adolescents and Young Adults. Journal of Homosexuality, 58:97-116.

Sousa-Poza, A. and Souza-Poza, A. A. (2003). Gender Differences in Job Satisfaction in Great Britain, 1991-2000: Permanent or Transitory? Applied Economics Letters, 10:691-694. 
Uppal, S. (2005). Disability, Workplace Characteristics and Job Satisfaction. International Journal of Manpower, 26:336-349.

Warr, P. (1999). Well-Being and the Workplace, in Kahnemann, D. Diener, E. and Schwarz, N. (Eds.), Wellbeing: the Foundations of Hedonic Psychology (p. 392412). New York: Russell Sage Foundation.

Women and Health Initiative. (2007). Activity Report. Attitudes and Behavior of Greek Society Toward Sexual Orientation. Greece. 
Table 1. Definitions of variables

Variable Definition
name

S

1 if the respondent is very dissatisfied; 2 if the respondent is dissatisfied, 3 if the respondent is neither dissatisfied nor satisfied; 4 if the respondent is satisfied; 5 if the respondent is very satisfied

$\mathrm{G} \quad 1$ if individual is gay; 0 otherwise

HW Mean of hourly wages (ln)

AGE Years of age

AGESQ Squared years of age

MARR 1 if individual is married; 0 otherwise

CHIL Number of respondent's children

IMM $\quad 1$ if individual is an immigrant; 0 otherwise

DIS 1 if individual is limited in kind or amount of work, has a mobility limitation, or has a personal care limitation; 0 otherwise

MHS Mean of adverse mental health symptom (CES-D 20 items) for last week [see footnote no. 4]

SCHOL $\quad 1$ if individual has completed minimum mandatory education; 0 otherwise

GRAD $\quad 1$ if individual has graduated from a high school; 0 otherwise

UNIV $\quad 1$ if individual has university or a technical school diploma; 0 otherwise

PC $\quad 1$ if individual has computer skills; 0 otherwise

ENGL $\quad 1$ if individual has knowledge of English; 0 otherwise

EXPER Years of actual working experience

EXPERQ Squared years of actual working experience

WHITE $\quad 1$ if individual's occupation is among managerial or professional specialties, or the individual works in a technical, sales, or administrative support position; 0 otherwise

BLUE 1 if individual's occupation is among precision production, craft, or repair occupations, or the individuals works as an operator, fabricator or labourer; 0 otherwise

SERV 1 if individual's occupation is among food preparation, protective service occupation, ground cleaning and maintenance occupations, personal care and healthcare support occupations

PUBL $\quad 1$ if individual is employed in the public sector; 0 if individual is employed in the private (PRIV) sector

FULL $\quad 1$ if individual is a full time employee, 0 otherwise (i.e. part time employee; PART) 
Table 2. Descriptive statistics

$\begin{array}{lll}\text { Heterosexual } & \text { Gay } & \text { Difference } \\ \text { Employees } & \text { Employees } & \text { test }\end{array}$
(1)
(2)
(3)

Number of observations

6,305

277

Satisfaction with total pay

3.16

2.87

$4.17(1.85) * * *$

Satisfaction with promotion prospects

3.23

2.92

$3.97(1.13) * * *$

Satisfaction with respect received from supervisor

3.36

2.95

$4.34(0.83)^{* * *}$

Mean hourly earnings (ln)

3.61

3.43

$2.52(1.19)^{* * *}$

Mean age

35.71

34.07

$1.42(1.12)$

Percentage who are married

$65.56 \%$

$3.24 \%$

$3.46(0.62)^{* * *}$

Mean number of individuals' children

0.91

0.02

$4.17(1.37)^{* * * *}$

Percentage who are immigrants

$6.36 \%$

$5.18 \%$

$1.93(0.92)^{*}$

Percentage with disability limitations

$5.26 \%$

$3.25 \%$

$2.05(1.03)^{* *}$

Mean value of the adverse mental health symptoms

1.86

1.87

$1.48(1.27)$

Percentage completing minimum mandatory

$95.49 \%$

$96.38 \%$

$1.34(1.20)$

education

Percentage of high school graduates

Percentage of university or technical school

$83.48 \%$

$82.22 \%$

$1.42(0.86)$

$45.78 \%$

$45.12 \%$

$1.54(1.00)$

graduates

Percentage with computing skills

$\begin{array}{lll}69.34 \% & 79.06 \% & 2.58(1.08)^{* * *} \\ 47.31 \% & 42.59 \% & 2.13(0.76)^{* * *} \\ 89.92 \% & 92.01 \% & 3.40(1.10)^{* * *} \\ 14.79 & 13.48 & 1.82(1.25) \\ 39.66 \% & 36.24 \% & 1.98(0.96)^{* *} \\ 49.45 \% & 54.87 \% & 2.32(1.07)^{* * *} \\ 10.88 \% & 8.30 \% & 1.93(1.85)^{*} \\ 39.49 \% & 41.51 \% & 1.82(1.45) \\ 59.92 \% & 58.48 \% & 1.79(1.28) \\ 87.66 \% & 81.93 \% & 2.17(0.65)^{* * *}\end{array}$

Percentage with English skills

Percentage with driving license

Mean years of experience

Percentage in white-collar jobs

Percentage in blue-collar jobs

Percentage in service occupations

Percentage in public sector

Percentage in private sector

Percentage of full-time employment

$87.66 \%$

$81.93 \%$

$2.17(0.65)^{* * *}$

Notes: Data Source, Athens Area Study (2008). Standard errors are in parenthesis. ***Significant at the $1 \%$ level. ** Significant at the 5\% level. *Significant at the $10 \%$ level. 
Table 3. Distribution of reported job satisfaction measures

\begin{tabular}{|c|c|c|c|c|c|c|c|c|c|}
\hline & $\begin{array}{l}\text { Satisfactio } \\
\text { total pay }\end{array}$ & with & $\begin{array}{l}\text { Difference } \\
\text { test }\end{array}$ & $\begin{array}{l}\text { Satisfactio } \\
\text { promotion } \\
\text { prospects }\end{array}$ & with & $\begin{array}{l}\text { Difference } \\
\text { test }\end{array}$ & $\begin{array}{l}\text { Satisfactic } \\
\text { respect re } \\
\text { from supe }\end{array}$ & $\begin{array}{l}\text { with } \\
\text { eived } \\
\text { visor }\end{array}$ & $\begin{array}{l}\text { Difference } \\
\text { test }\end{array}$ \\
\hline & $\begin{array}{l}\text { Heterosexual } \\
\text { Employees }\end{array}$ & $\begin{array}{l}\text { Gay } \\
\text { Employees }\end{array}$ & & $\begin{array}{l}\text { Heterosexual } \\
\text { Employees }\end{array}$ & $\begin{array}{l}\text { Gay } \\
\text { Employees }\end{array}$ & & $\begin{array}{l}\text { Heterosexual } \\
\text { Employees }\end{array}$ & $\begin{array}{l}\text { Gay } \\
\text { Employees }\end{array}$ & \\
\hline $\begin{array}{l}\text { Very } \\
\text { Dissatisfied }\end{array}$ & $6.22 \%$ & $12.02 \%$ & $\begin{array}{l}4.89 \\
(1.17)^{* * *}\end{array}$ & $16.01 \%$ & $19.44 \%$ & $\begin{array}{l}3.76 \\
(1.08)^{* * *}\end{array}$ & $6.47 \%$ & $19.33 \%$ & $\begin{array}{l}4.36 \\
(1.60)^{* * *}\end{array}$ \\
\hline Dissatisfied & $22.10 \%$ & $25.23 \%$ & $\begin{array}{l}2.32 \\
(1.18)^{* *}\end{array}$ & $18.33 \%$ & $24.02 \%$ & $\begin{array}{l}3.07 \\
(0.97)^{* * *}\end{array}$ & $11.62 \%$ & $18.14 \%$ & $\begin{array}{l}3.57 \\
(0.88)^{* * *}\end{array}$ \\
\hline Neither & $28.03 \%$ & $47.01 \%$ & $\begin{array}{l}3.71 \\
(1.30)^{* * *}\end{array}$ & $25.14 \%$ & $34.55 \%$ & $\begin{array}{l}4.14 \\
(1.84)^{* * *}\end{array}$ & $26.83 \%$ & $37.21 \%$ & $\begin{array}{l}5.28 \\
(2.11)^{* * *}\end{array}$ \\
\hline Satisfied & $35.24 \%$ & $12.06 \%$ & $\begin{array}{l}4.18 \\
(1.28)^{* * *}\end{array}$ & $34.77 \%$ & $17.70 \%$ & $\begin{array}{l}5.10 \\
(1.35)^{* * *}\end{array}$ & $37.64 \%$ & $21.02 \%$ & $\begin{array}{l}3.89 \\
(1.25)^{* * *}\end{array}$ \\
\hline $\begin{array}{l}\text { Very } \\
\text { Satisfied }\end{array}$ & $8.41 \%$ & $3.68 \%$ & $\begin{array}{l}4.42 \\
(2.00)^{* * *}\end{array}$ & $5.75 \%$ & $4.29 \%$ & $\begin{array}{l}2.04 \\
(1.03)^{* *}\end{array}$ & $17.44 \%$ & $4.30 \%$ & $\begin{array}{l}4.43 \\
(0.74)^{* * *}\end{array}$ \\
\hline
\end{tabular}

Notes: Data Source, Athens Area Study (2008). Standard errors are in parenthesis. ***Significant at the $1 \%$ level. ** Significant at the 5\% level. *Significant at the $10 \%$ level. 
Table 4. Estimates of job satisfaction

\begin{tabular}{|c|c|c|c|}
\hline & $\begin{array}{l}\text { Satisfaction with } \\
\text { Total Pay }\end{array}$ & $\begin{array}{l}\text { Satisfaction with } \\
\text { Promotion Prospects }\end{array}$ & $\begin{array}{l}\text { Satisfaction with Respect } \\
\text { Received from } \\
\text { Supervisor }\end{array}$ \\
\hline Sexual orientation & $-0.214(0.066)^{* * *}$ & $-0.286(0.063) * * *$ & $-0.501(0.066)^{* * *}$ \\
\hline Wages $(\ln )$ & $0.173(0.021) * * *$ & $0.177(0.026) * * *$ & $0.179(0.026)^{* * *}$ \\
\hline Age & $-0.008(0.002)^{* * *}$ & $-0.009(0.002)^{* * *}$ & $-0.008(0.002)^{* * *}$ \\
\hline $\mathrm{Age}^{2}$ & $0.0007(0.00001)^{* * *}$ & $0.0006(0.00001)^{* * *}$ & $0.0007(0.00002)^{* * *}$ \\
\hline Married & $0.042(0.012)^{* * *}$ & $0.045(0.010)^{* * *}$ & $0.044(0.011)^{* * *}$ \\
\hline Number of children & $0.016(0.012)$ & $0.013(0.012)$ & $0.016(0.011)$ \\
\hline Immigrants & $-0.020(0.005)^{* * *}$ & $-0.019(0.010)^{* *}$ & $-0.019(0.008) * * *$ \\
\hline $\begin{array}{l}\text { University or technical } \\
\text { school diploma }\end{array}$ & $-0.027(0.010)^{* * *}$ & $0.073(0.038)^{* *}$ & $0.069(0.023)^{* * *}$ \\
\hline $\begin{array}{l}\text { Basic knowledge of } \\
\text { computer }\end{array}$ & $-0.010(0.008)$ & $-0.009(0.007)$ & $-0.009(0.010)$ \\
\hline $\begin{array}{l}\text { Basic knowledge of } \\
\text { English }\end{array}$ & $-0.050(0.043)$ & $-0.050(0.042)$ & $-0.051(0.040)$ \\
\hline Disability status & $-0.092(0.014) * * *$ & $-0.098(0.012) * * *$ & $-0.093(0.019) * * *$ \\
\hline $\begin{array}{l}\text { Adverse mental health } \\
\text { symptoms }\end{array}$ & $-0.012(0.004) * * *$ & $-0.018(0.005)^{* * *}$ & $-0.012(0.005)^{* * *}$ \\
\hline $\begin{array}{l}\text { Adverse mental health } \\
\text { symptoms x } \\
\text { sexual orientation }\end{array}$ & $-0.002(0.006)$ & $-0.002(0.004)$ & $-0.003(0.003)$ \\
\hline Work experience & $-0.071(0.038)^{*}$ & $-0.070(0.037)^{*}$ & $-0.072(0.038)^{*}$ \\
\hline Work experience $^{2}$ & $0.0001(0.00001)^{* * *}$ & $0.0001(0.00001)^{* * *}$ & $0.0001(0.00001)^{* * *}$ \\
\hline White collar job & $-0.018(0.010)^{* *}$ & $0.059(0.017)^{* * *}$ & $0.058(0.015)^{* * *}$ \\
\hline Blue collar job & $0.048(0.020)^{* * *}$ & $-0.022(0.012)^{*}$ & $-0.024(0.012)^{* *}$ \\
\hline Public job & $0.043(0.020)^{* * *}$ & $0.042(0.020)^{*}$ & $0.045(0.021)^{* * *}$ \\
\hline Full time employment & $0.053(0.038)$ & $0.052(0.039)$ & $0.053(0.035)$ \\
\hline Pseudo $\mathrm{R}^{2}$ & 0.005 & 0.007 & 0.006 \\
\hline Observations & 6,582 & 6,582 & 6,582 \\
\hline
\end{tabular}

Notes: Data Source, Athens Area Study (2008). Standard errors are in parenthesis. ***Significant at the $1 \%$ level. ** Significant at the $5 \%$ level. *Significant at the $10 \%$ level. 
Table 5. Estimates of wage differences between gay and heterosexual men per each satisfaction scale component and job facet

\begin{tabular}{llll}
\hline Satisfaction with & $\begin{array}{l}\text { Satisfaction with } \\
\text { promotion prospects }\end{array}$ & $\begin{array}{l}\text { Satisfaction with } \\
\text { respect received } \\
\text { from supervisor }\end{array}$ \\
\hline Very Dissatisfied & $-0.060(0.018)^{* * *}$ & $-0.068(0.021)^{* * *}$ & $-0.056(0.018)^{* * *}$ \\
Dissatisfied & $-0.058(0.015)^{* * *}$ & $-0.055(0.010)^{* * *}$ & $-0.052(0.019)^{* * *}$ \\
Neither & $-0.026(0.012)^{* * *}$ & $-0.037(0.013)^{* * * *}$ & $-0.048(0.010)^{* * *}$ \\
Satisfied & $-0.007(0.008)$ & $-0.017(0.005)^{* * *}$ & $-0.025(0.011)^{* *}$ \\
Very Satisfied & $-0.007(0.006)$ & $-0.014(0.011)$ & $-0.016(0.009)^{*}$ \\
\hline
\end{tabular}

Notes: Data Source, Athens Area Study (2008). Each cell is a separate semi-logarithmic regression outcome on the sexual orientation dummy variable. Each regression incorporates the same independent variables as in Table 4. Standard errors are in parenthesis. ***Significant at the $1 \%$ level. ** Significant at the 5\% level. *Significant at the 10\% level. 